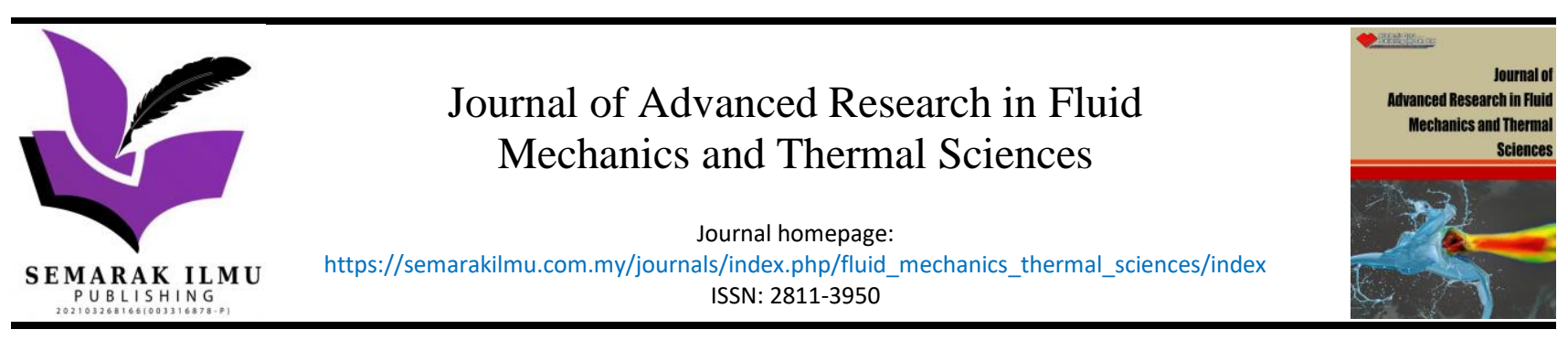

\title{
Comparison of Diesel Engine Performance between a Mechanical Pump and a Common Rail Fuel Injection System Equipped with Real-Time Non- Surfactant Emulsion Fuel Supply System
}

\author{
Md Mujibur Rahman ${ }^{1}$, Wira Jazair Yahya ${ }^{1,}{ }^{*}$, Hasannuddin Abd Kadir ${ }^{2}$, Ahmad Muhsin Ithnin ${ }^{1}$, \\ Qayyum Mohd Tamam ${ }^{1}$, Hasbullah Abdul Rahman ${ }^{3}$ \\ Advanced Vehicle System, Malaysia-Japan International Institute of Technology (MJIIT), Universiti Teknologi Malaysia, 54100, Kuala Lumpur, \\ Malaysia \\ 2 College of Engineering, Universiti Teknologi MARA, Cawangan Johor, Kampus Pasir Gudang, 81750 Masai Johor, Malaysia \\ 3 RTES Technology (M) Sdn. Bhd., Lot 33004/5, Jalan Kebun, Kampung Jawa, 41000 Klang, Selangor, Malaysia
}

\section{ARTICLE INFO}

\section{Article history:}

Received 27 August 2021

Received in revised form 3 December 2021

Accepted 25 December 2021

Available online 24 January 2022

\section{Keywords:}

Diesel vehicles; commonrail; Emulsion

fuel; Non-Surfactant; NOx; smoke

\section{ABSTRACT}

The global focus in emulsion fuels is due to the advantages over conventional diesel fuels. It has the capabilities to simultaneously reduce the emissions of NOx and smoke. It also said to reduce the fuel consumption of diesel engine by significant percentages. However, due to the interdependency on surfactant, emulsion fuel does not seem to be possible as alternative fuel in an economic perspective. This is because of the high market price of the commercial surfactant. Therefore, this research focused on non-surfactant W/D that produced by a system known as Real-Time Non-Surfactant Emulsion Fuel Supply System (RTES). RTES has been applied with the goal of investigating the impact on exhaust emissions and fuel consumption of a mechanical pump fuel injection system diesel vehicle (MP) and a common rail fuel injection system diesel vehicle (CR). A one-ton truck represents as MP (Mechanical Pump) and an SUV represent as CR (Common rail) are the test vehicles for the said research. The non-surfactant W/D with 6.5 wt.\% of water produced by the RTES used as the test fuel and named as E6.5. It has been emulsified in the RTES right before being injected into the diesel vehicles. The testing was performed on a chassis dynamometer following the West Virginia University 5-peak cycles. The findings show that the utilization of non-surfactant W/D has increased the fuel consumption by $7.39 \%$ for MP and 3.2\% for CR respectively as compared with base diesel fuel. NOx, smoke emissions and exhaust temperature have significantly reduced by the $M P$ relative to $C R$ vehicles. Overall, the concept of non-surfactant W/D seems to have implementation potential for reducing harmful emissions from both diesel-powered vehicles.

\section{Introduction}

The industries and transport sector are largely dependent on fossil energies for which humanity and environmental pressure is extensive. High demand and growing diesel prices have raised

\footnotetext{
* Corresponding author.

E-mail address: wira@utm.my

https://doi.org/10.37934/arfmts.91.2.4150
} 
concerns about energy and economic security, while pollution has exacerbated environmental degradation and health problems [1-3]. Transport contributed to $75 \%$ of the world's total fuel combustion-based greenhouse gas emissions, and about $25 \%$ of those emissions are due to road transport [4]. Whereas diesel engines are significantly more compact than gasoline engines, they are also more costly to manufacture. The diesel engine will probably last longer and require less routine maintenance. Additionally, diesel engines have long been renowned for their dependability and low fuel consumption. Even though diesel engines are preferred, they emit harmful exhaust emissions, particularly Particulate Matter (PM), Nitrogen Oxides ( $\left.\mathrm{NO}_{\mathrm{x}}\right)$, Carbon Monoxide (CO), and Carbon Dioxide $\left(\mathrm{CO}_{2}\right)$ [5-8]. It has recently come to light that emulsion fuel from water in-diesel (W/D) is one of the alternative fuels which most common with researchers because it offers a solution for the worldwide need to minimize $\mathrm{NO}_{\mathrm{x}}$ and $\mathrm{PM}$ emissions while also improving combustion efficiency and has received a lot of attention as a potential improvement on the environment and human health $[9,10]$.

Nazha et al., [11], investigated the W/D on DI Ford diesel engine with EGR on a 2.5 L, 4- cylinder water inject on the intake manifold. The results showed that the emissions of $\mathrm{NO}_{\mathrm{x}}$ were reduced by exhaust gas recirculation, but smoke grew. Use of W/D emulsion without any additional cost the engine's performance or other pollutant emissions reduced around $60 \%$. It cuts $\mathrm{NO}_{\mathrm{x}}$ and smoke emissions while minimally affecting engine performance. The issue of stability, which can only be stable for a given period, is the main weakness in the use of emulsion fuel. Using W/D is very costly due to the surfactant and its preparation and which cannot be cost-effective in massive commercialization [12]. In the US, the W/D concept was applied to lorries. To conduct the experiment, they applied W/D in a ratio of 25 vol\% of water. The fuel costs of this system have been proved to be $20 \%$ savings and the emissions of $\mathrm{NO}_{\mathrm{x}}$ and $\mathrm{PM}$ can be reduced by $55 \%-80 \%$ at the same time. However, the use of surfactants was not clearly indicated in this device. Kim et al., [13], investigated a $2.0 \mathrm{~L} 4$-cylinder common-rail diesel engine with turbocharger using emulsion fuel and demonstrated that fuel consumption decreases at $4.4 \%$ to $12.6 \%$ and $\mathrm{NO}_{\mathrm{x}}$ reduced by 30 to $50 \%$ and smoke emissions decreased by $80 \%$.

Real-Time Non-Surfactant Emulsion Fuel Supply System (RTES) is the concept, which eliminates the dependence on surfactants to produce emulsions with long stability. It focuses primarily on the production of W/D by constantly mixing diesel to water in an in-line mixing system, which is quickly suppliable to the engine. Ithnin et al., [14], have shown without use of surfactant, emulsion fuel that substantially reduced exhaust emissions of both $\mathrm{NO}_{\mathrm{x}}$ and $\mathrm{PM}$, compared to base diesel fuel the average reduction was $31.66 \%$ and $16.33 \%$ respectively. Ramlan et al., [15], run a 1-ton truck which 4- stroke and four cylinders, direct injection engine by using non surfactant emulsion fuel, it shows the fuel saving up to $7.39 \%$. The $\mathrm{NO}_{\mathrm{x}}$ emissions are lower by $23 \%$, and $\mathrm{CO}$ emissions are slightly higher by $41 \%$, compared to the base diesel, with a reduction in smoke emissions at all operating speeds. However, no comprehensive assessment was published of such studies and the full impact of the non-surfactant emulsion fuel with mechanical and common rail injection of engine emissions has not been published. Thus, the aim of the paper, to investigate of comparison between mechanical pump fuel injection system (MP) and common rail injection systems (CR) to determine the effect of W/D on diesel engine performance and exhaust emission using RTES.

\section{Experiment Methodology}

\subsection{Test Fuel}

The test fuel used in this analysis is emulsion fuel with a quantity of 6.5 wt\% water content (E6.5), which is classified as E6.5 for both test vehicles. E6.5 was used continuously during the trial. The E6.5 
was formulated using RTES, in which Euro 2M diesel (DE2) was combined with water injected through water injector in the mixing chamber.DE2 fuel is widely used, that can be bought from a commercial petrol station. Table 1 shows the fuel properties of DE2.

Table 1

The fuel properties of DE2

\begin{tabular}{lll}
\hline Properties & Unit & DE2 \\
\hline Calorific Value & $\mathrm{MJ} / \mathrm{kg}$ & 43.28 \\
Density @ $15^{\circ} \mathrm{C}$ & $\mathrm{kg} / \mathrm{L}$ & 0.8372 \\
Flash Point & ${ }^{\circ} \mathrm{C}$ & 68 \\
Cetane Number & - & 62.5 \\
Sulfur content & $\mathrm{ppm}$ & 320 \\
\hline
\end{tabular}

\subsection{Test Vehicles}

\subsubsection{Mechanical pump fuel injection diesel powered vehicle}

A one-ton NHR Isuzu truck was used as a mechanical pump test vehicle. This vehicle is equipped with a four-stroke, four-cylinder, naturally aspirated diesel engine that complies with Euro 2 emission standards. Table 2 represent the vehicle specifications. This vehicle was chosen because it is classified as a light-duty truck.

Table 2

Vehicle specifications of MP test vehicle

\begin{tabular}{ll}
\hline Parameter & Specification \\
\hline Model & Isuzu NHR 55E (4JB1) \\
Fuel injection system & Direct injection \\
Cylinder & 4 cylinders, in-line \\
Cooling system & Water-cooled \\
Displacement (L) & 2.8 \\
Maximum output (Ps/rpm) & $59(80) / 3600$ \\
Maximum torque (kg-m/rpm) & $175(17.8) / 2000$ \\
\hline
\end{tabular}

\subsubsection{Common rail fuel injection diesel powered vehicle}

A Sport Utility Vehicle with a commonrail fuel injection diesel engine, features a 4-stroke, fourcylinder, turbocharged and is designed to fulfil the emission regulations of Euro 2 . The details specification of the vehicle is given in Table 3.

Table 3

Vehicle specifications of $\mathrm{CR}$ test vehicle

\begin{tabular}{ll}
\hline Parameter & Specification \\
\hline Model & Santa Fe 2009 \\
Fuel injection system & Common Rail Direct Injection \\
Engine type & 4 Cylinder, water-cooled, inline engine \\
Displacement volume $(\mathrm{cc})$ & $2200 \mathrm{cc}$ \\
Maximum output $(\mathrm{Ps} / \mathrm{rpm})$ & $194.3 \mathrm{bhp@3800} \mathrm{rpm}$ \\
Maximum torque (N-m/rpm) & $420.7 \mathrm{~N}-\mathrm{m} @ 1800-2500 \mathrm{rpm}$ \\
Drive Type & $4 \mathrm{WD}$ \\
\hline
\end{tabular}




\subsection{Chassis Dynamometer Test}

The chassis dynamometer test method traditionally been used to investigate the vehicle's exhaust emissions and performance. The key benefit of the laboratory dynamometer test is the ability to monitor test conditions, including temperatures, and driving conditions [16]. The chassis dynamometer testing is conducted following SAE J1082 standard. The chassis dynamometer system can reproduce current driving conditions, such as conditions of idle, acceleration, cruising, and deceleration. The schematic diagram for measuring related data on the chassis dynamometer is shown in Figure 1. The rollers can also be programmed to simulate friction loss and aerodynamic strength.

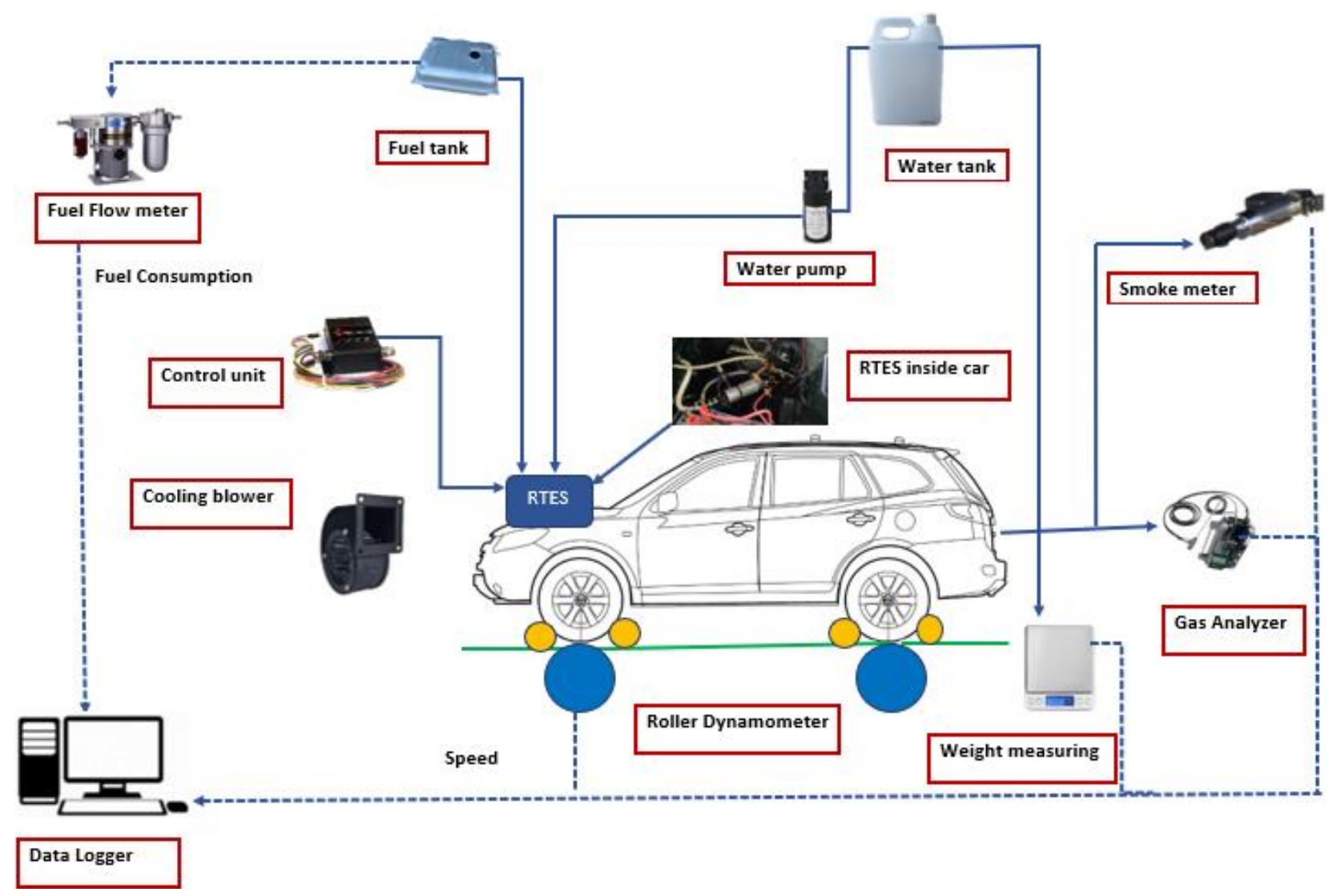

Fig. 1. Schematic diagram of chassis dynamometer testing

\subsection{Fuel Line Configuration}

The test vehicle's fuel line must be modified to incorporate RTES. In comparison to a static engine, the important issue of vehicles is the engine's fuel return line. The return fuel flows back to the tank in the normal operation of a diesel engine. However, return fuel will not be returned to the tank when using E6.5 because the separation of diesel and water will cause problems later to the diesel engine. Instead, the return E6.5 from the engine was channel back to RTES so that the reemulsification process can be done to ensure E6.5 that introduced into the engine is always in a stable state. The fuel flow is illustrated in Figure 2. 


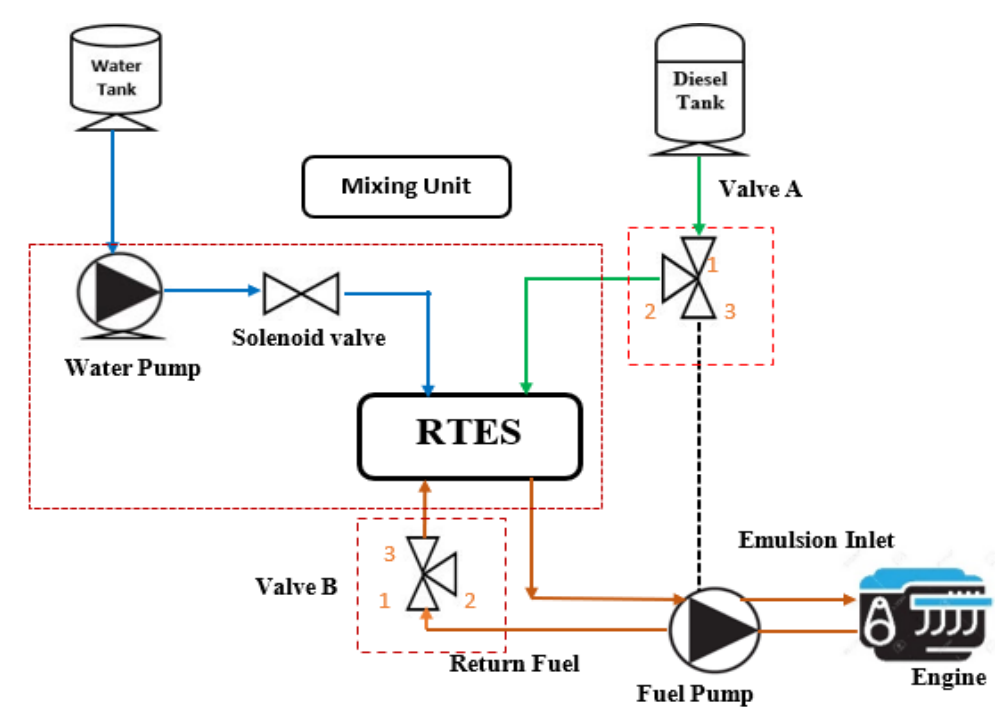

Fig. 2. Configuration of fueling system embedded with RTES

\subsection{Testing Cycle}

This study follows the test procedure for the chassis dynamometer test of the driving cycle known as the West Virginia University (WVU), 5 peak cycles. The cycle is chosen in contrast to other types of driving cycles since it was specifically constructed for general light-vehicle chassis testing. This cycle includes 5 phases, with acceleration at the peak speed in each section, short stationary service and finally a deceleration point back to idle. The five top speeds, called cycle-1,2,3,4,5 is often indicated as the number of accelerations. The average length of the cycle is $900 \mathrm{~s}$ and a distance depends on the speed of the vehicle. The used E6.5 compares the CR with the MP and then varies with the peaks in WVU's 5-peak driving time. Figure 3 shows the WVU 5 peak cycle for the chassis dynamometer test.

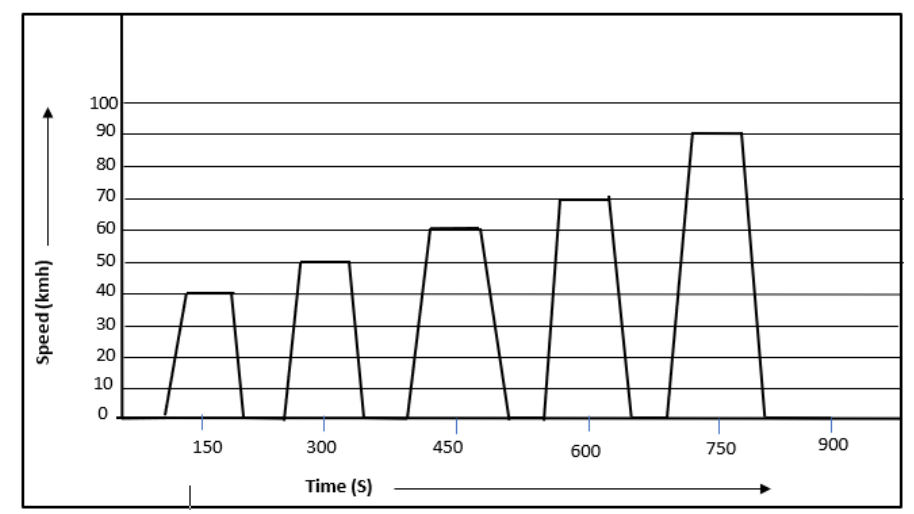

Fig. 3. Speed profile of modified WVU 5-Peak Cycle

\section{Result and Discussion}

\subsection{Nitrogen Oxides $\left(\mathrm{NO}_{x}\right)$}

The main advantage of using E6.5 in diesel engines is a reduction in $\mathrm{NO}_{\mathrm{x}}$ emissions. Figure 4 illustrates the variation in $\mathrm{NO}_{\mathrm{x}}$ emissions over time for DE2 and its E6.5 under the WVU 5 peak cycles. The measurements of $\mathrm{NO}_{\mathrm{x}}$ emissions showed a different compliance with $\mathrm{E} 6.5$ and were designed to satisfy the emissions demands of Euro 2 for MP and CR. Meanwhile, for all test fuels between Cycle 1 to 5 , cycle 5 shows, the highest values for $\mathrm{NO}_{\mathrm{x}}$ emissions have been recorded. At that time, the 
peak of $\mathrm{NO}_{\mathrm{x}}$ is $712 \mathrm{ppm}, 529 \mathrm{ppm}$, and $662 \mathrm{ppm}, 619 \mathrm{ppm}$, respectively for MP and CR DE2, E6.5. All emulsions have been found, successfully to reduce $\mathrm{NO}_{\mathrm{x}}$ emissions with respect to E6.5. The $\mathrm{NO}_{\mathrm{x}}$ fraction of light-duty trucks emits significantly more than that of passenger cars, the measurements indicate that the $\mathrm{NO}_{2}$ mass fraction is highly dependent on the absolute level of $\mathrm{NO}_{x}$ emissions, with a reduction of $29.18 \%$ in $\mathrm{NO}_{x}$ emissions from light-duty trucks and $18.69 \%$ in CR test vehicles when using E6.5. This is because water content in the fuel reduces the latent heat of vaporisation, which in turn lowers the temperature in the combustion chamber which reduces formation of $\mathrm{NO}_{\mathrm{x}}$. Use of emulsion fuel the average flame temperature is much lower, resulting in a lower concentration of $\mathrm{NO}_{x}[14,15]$.

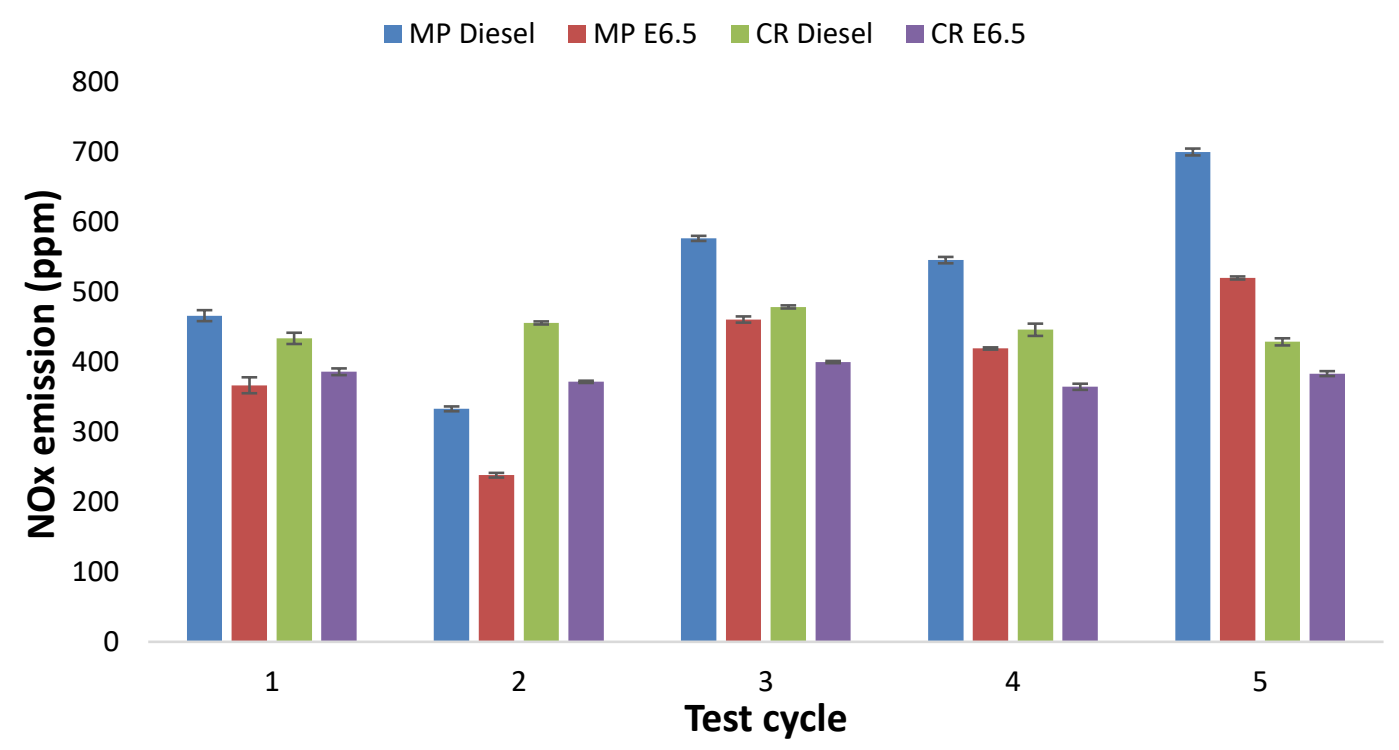

Fig. 4. Variation of $\mathrm{NO}_{x}$ emission of vehicle

\subsection{Exhaust Temperature}

Figure 5 showed under the WVU 5 peak-cycle test the E6.5 used in the engines can slightly reduce the exhaust temperature as compared with the DE2 fuel. From the graph, it can be inferred that the initial temperature is lower while the vehicle speed is lower, and it rises to its maximum once-stable value during the peak of the cycle. In average the use of E6.5 led to lower operating temperatures due to combustion heat being absorbed by the water phase [19]. The exhaust temperature with MP is lower at low speed vehicle operation and become high at high speed vehicle operation as compared with CR. The average exhaust temperature variation in MP and CR with DE2 is $3.65 \%$ and $3 \%$ respectively. Due to the better dispersion of the emulsion fuel, a heat sink effect occurs, resulting in a lower combustion temperature. As water is used in the combustion, the burning temperature will be decreased [20]. 


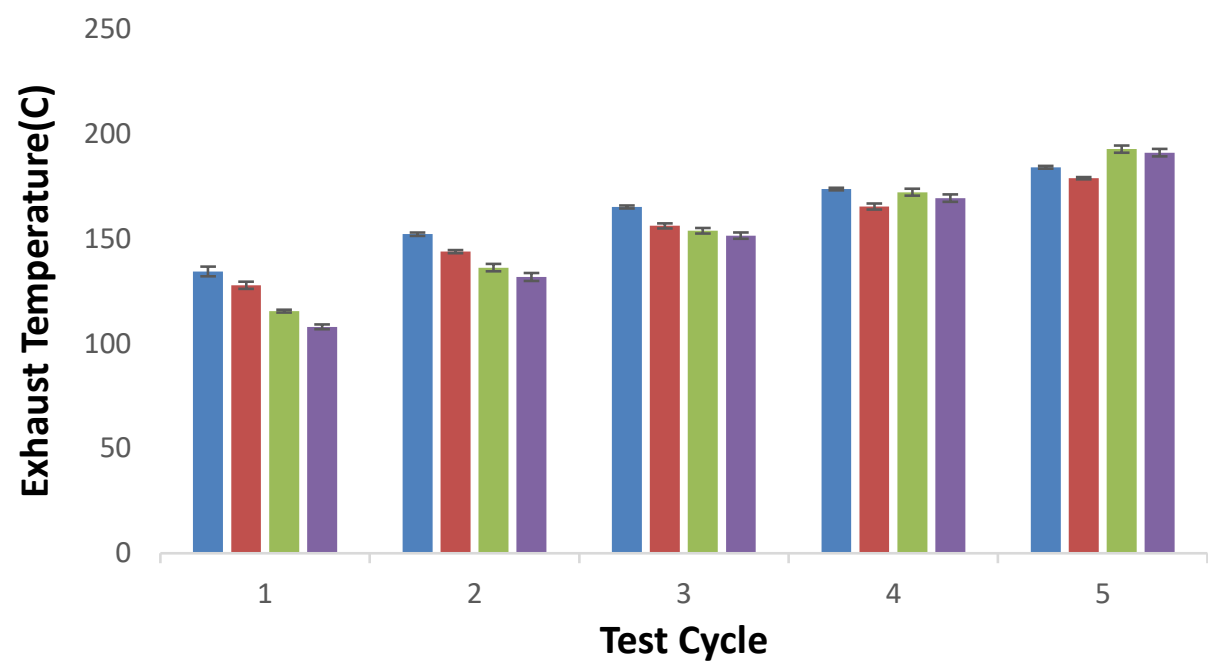

Fig. 5. Exhaust temperature of vehicle

\subsection{Smoke}

An incomplete combustion and the partially reacting carbon content in fuel are the main reasons for the smoke produced in diesel engines. Smoke is a solid particle that adheres to exhaust gases and separate, obscures, or gets into the light stream of gas. When the fuel supply is rich, or when the air intake is limited, grey or black smoke is emitted. Smoke emissions can also be influenced by the properties of the fuel [10]. Figure 6 illustrates the relationship between smoke quantity and vehicle speed for MP and CR vehicles. However, the smoke measurement for MP vehicle was using Bosch smoke meter while for $C R$ vehicle was using opacity meter. Quantitatively it is not possible to compare smoke emissions between MP and CR vehicles. Qualitatively, it can clearly observe that E6.5 can reduce smoke emission significantly.

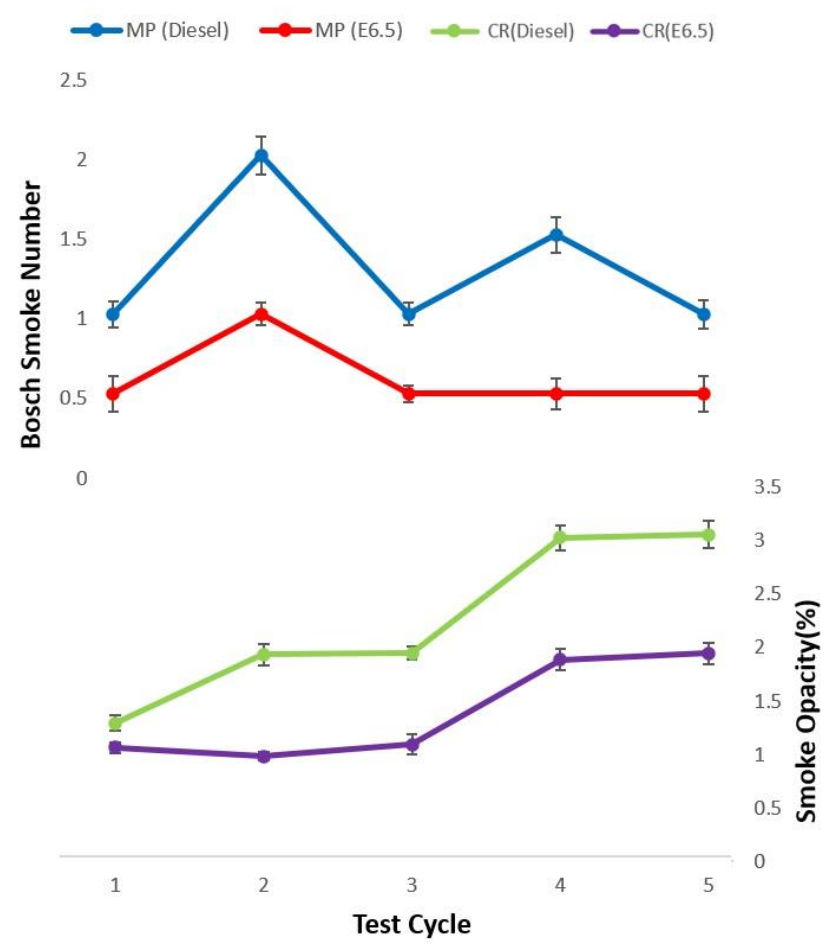

Fig. 6. Smoke emission of vehicles 


\subsection{Fuel Consumption}

The difference in fuel consumption caused by E6.5 is depicted in Figure 7. This figure demonstrates that E6.5 consumption was lower for both vehicles than base fuel consumption. The total fuel consumption of E6.5 fuels was only considering diesel fuel consumption. The reduction in fuel consumption associated with E6.5 is due to a micro-explosion caused by the volatility difference between water and diesel. It results in secondary atomization because of the water droplets evaporating rapidly and violently within the larger diesel droplets. Secondary atomization contributes better combustion, resulting in decreased fuel consumption [21]. In contrast to DE2, E6.5 extend the ignition delay and permit a larger amount of fuel to burning during combustion process $[15,16]$. Commonrail fuel injection system in CR vehicle injects the test fuel at significantly higher pressure. As compared with mechanical injection pump fuel injection system, the atomization of injected fuel will be better in CR diesel engine, thus leads to complete combustion and reduced fuel consumption. That was the main reason of lower fuel consumption of CR vehicle as compared with MP vehicle of using DE2 fuel. The reduction of fuel consumption of using E6.5 for MP and CR vehicles are 7.33\% and $3.2 \%$ respectively. Since the CR vehicle already having a good atomization of injected fuel due to its high injection pressure, the secondary atomization affects due to micro-explosion of using E6.5 in $\mathrm{CR}$ vehicle was not significant. Therefore, MP vehicles fuelled with $\mathrm{E} 6.5$ can have higher improvement of fuel consumption than CR vehicle fuelled with E6.5.

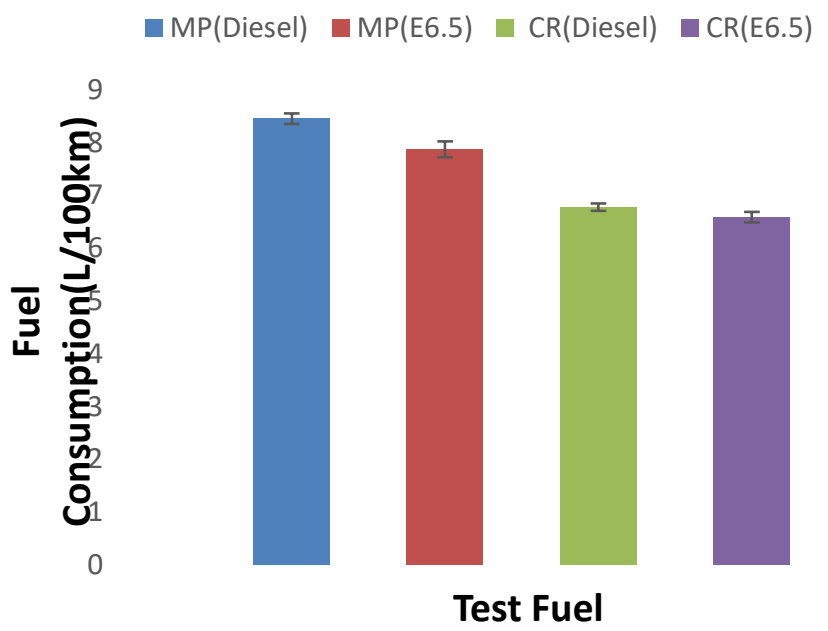

Fig. 7. Fuel consumption of vehicle

\section{Conclusions}

A study to compare fuel consumption and exhaust emissions of a mechanical pump fuel injection diesel vehicle (MP) with a commonrail fuel injection diesel vehicle (CR) fuelled with non-surfactant water-in-diesel emulsion fuel (E6.5) has been carried out. The following points can be summarized based on the experimental results

i. E6.5 shows lower fuel consumption as compared with DE2 for both MP and CR vehicles.

ii. Improvement of fuel consumption for CR vehicle of using E6.5 is lower than MP vehicle due to its high-pressure fuel injection effect.

iii. NOx, smoke, and thermal emissions are lower for both vehicles fuelled with E6.5 as compared with DE2 fuel.

iv. Improvement of all emissions of using E6.5 as compared with base diesel fuel from MP vehicle are higher than $\mathrm{CR}$ vehicle. 


\section{Acknowledgement}

We want to express our gratitude to the Malaysia-Japan International Institute of Technology (MJIIT), Universiti Teknologi Malaysia for providing facilities and equipment for these research activities. The highest appreciation to the Ministry of Education Malaysia for their financial support through the Universiti Teknologi Malaysia Transdisciplinary Research Grant (Q.K130000.3543.05G08).

\section{References}

[1] Zulkurnai, Fatin Farhanah, Norhidayah Mat Taib, Wan Mohd Faizal Wan Mahmood, and Mohd Radzi Abu Mansor. "Combustion Characteristics of Diesel and Ethanol Fuel in Reactivity Controlled Compression Ignition Engine." Journal of Advanced Research in Numerical Heat Transfer 2, no. 1 (2020): 1-13.

[2] Maksom, Mohammad Syahadan, Nurul Fitriah Nasir, Norzelawati Asmuin, Muhammad Faqhrurrazi Abd Rahman, and Riyadhthusollehan Khairulfuaad. "Biodiesel Composition Effects on Density and Viscosity of Diesel-Biodiesel Blend: A CFD Study." CFD Letters 12, no. 4 (2020): 100-109. https://doi.org/10.37934/cfdl.12.4.100109

[3] Hayder, G., and P. Puniyarasen. "Identification and evaluation of wastes from biodiesel production process." Journal of Advanced Research in Applied Sciences and Engineering Technology 3, no. 1 (2016): 21-29.

[4] Statistics, I. E. A. "IEA Statistics: CO2 emissions from fuel combustion-Highlights." International Energy Agency (2016).

[5] Erdiwansyah, Erdiwansyah, Mahidin Mahidin, Ahmad Fitri Yusop, Muhammad Zaki, Rizalman Mamat, Muhibbuddin Muhibbuddin, Ratna Eko Sardjono, Nor Azwadi Che Sidik, and Husni Husin. "Investigation of The Effect BiodieselButanol-Water Fuel Blend Pressure on A Single-Cylinder Diesel Engine." Journal of Advanced Research in Fluid Mechanics and Thermal Sciences 79, no. 2 (2021): 39-47. https://doi.org/10.37934/arfmts.79.2.3947

[6] Mahdi, Wan Nur Izzati Wan, Ahmad Muhsin Ithnin, Wira Jazair Yahya, Muhammad Adib Abdul Rashid, Muhamad Aliff Zaharim, Mikhael Mukhlasein Ahmad, Hasannuddin Abd Kadir, and Ili Fatimah Abdul Razak. "Effect of Electrical Load On the Emulsification Methods of Inline Mixing System RTES Produced by The Static Mixer and Ultrasonic on Fuel Consumption and Emission Characteristics." Journal of Advanced Research in Fluid Mechanics and Thermal Sciences 78, no. 1 (2021): 88-99. https://doi.org/10.37934/arfmts.78.1.8899

[7] Ramlan, N. A., A. A. Abdullah, and W. J. Yahya. "Combustion Performance and Exhaust Emission Analysis of Diesel Engine using Waste Cooking Oil." Journal of Advanced Research in Fluid Mechanics and Thermal Sciences 12, no. 1 (2015): 11-20.

[8] Suhaimi, Nur Athirah, Baljit Singh, and Muhammad Fairuz Remeli. "Experimental study on waste heat recovery system of an internal combustion engine using thermoelectric technology." In IOP Conference Series: Earth and Environmental Science, vol. 463, no. 1, p. 012141. IOP Publishing, 2020. https://doi.org/10.1088/1755$1315 / 463 / 1 / 012141$

[9] Ogunkoya, Dolanimi, Shuai Li, Orlando J. Rojas, and Tiegang Fang. "Performance, combustion, and emissions in a diesel engine operated with fuel-in-water emulsions based on lignin." Applied Energy 154 (2015): 851-861. https://doi.org/10.1016/i.apenergy.2015.05.036

[10] Hasannuddin, A. K., J. Y. Wira, R. Srithar, S. Sarah, M. I. Ahmad, S. A. Aizam, M. A. B. Aiman et al. "Effect of emulsion fuel on engine emissions-A review." Clean Technologies and Environmental Policy 18, no. 1 (2016): 17-32. https://doi.org/10.1007/s10098-015-0986-x

[11] Nazha, Marouan AA, Hobina Rajakaruna, and S. A. Wagstaff. "The use of emulsion, water induction and EGR for controlling diesel engine emissions." SAE Transactions (2001): 1205-1211. https://doi.org/10.4271/2001-01-1941

[12] Ithnin, Ahmad Muhsin, Hirofumi Noge, Hasannuddin Abdul Kadir, and Wira Jazair. "An overview of utilizing waterin-diesel emulsion fuel in diesel engine and its potential research study." Journal of the Energy Institute 87, no. 4 (2014): 273-288. https://doi.org/10.1016/i.joei.2014.04.002

[13] Kim, Moonchan, Jungmo Oh, and Changhee Lee. "Study on combustion and emission characteristics of marine diesel oil and water-in-oil emulsified marine diesel oil." Energies 11, no. 7 (2018): 1830. https://doi.org/10.3390/en11071830

[14] Ithnin, Ahmad Muhsin, Wira Jazair Yahya, Mohamad Azrin Ahmad, Nur Atiqah Ramlan, Hassanuddin Abdul Kadir, Nor Azwadi Che Sidik, and Tsuyoshi Koga. "Emulsifier-free Water-in-Diesel emulsion fuel: Its stability behaviour, engine performance and exhaust emission." Fuel 215 (2018): 454-462. https://doi.org/10.1016/j.fuel.2017.11.061

[15] Ramlan, Nur Atiqah, Wira Jazair Yahya, Ahmad Muhsin Ithnin, A. K. Hasannuddin, Siti Amiliyana Norazni, Nurul Aiyshah Mazlan, Dhani Avianto Sugeng, Nadia Dayana Bahar, and Tsuyoshi Koga. "Performance and emissions of light-duty diesel vehicle fuelled with non-surfactant low grade diesel emulsion compared with a high grade diesel in Malaysia." Energy Conversion and Management $130 \quad$ (2016): $192-199$. https://doi.org/10.1016/i.enconman.2016.10.057 
[16] Pang, Yanbo, Mark Fuentes, and Paul Rieger. "Trends in the emissions of Volatile Organic Compounds (VOCs) from light-duty gasoline vehicles tested on chassis dynamometers in Southern California." Atmospheric Environment 83 (2014): 127-135. https://doi.org/10.1016/j.atmosenv.2013.11.002

[17] Ramlan, Nur Atiqah, Wira Jazair Yahya, Ahmad Muhsin Ithnin, Hasannuddin Abd Kadir, Khairil Anwar Abu Kassim, Hasbullah Abdul Rahman, Arif Fahim Ezzat Chan, Nurul Aisyah Mazlan, Muhammad Adib Abdul Rashid, and Dhani Avianto Sugeng. "Emissions and performance analysis of diesel powered road vehicle equipped with real-time nonsurfactant emulsion fuel supply system." Fuel 273 (2020): 117257. https://doi.org/10.1016/i.fuel.2020.117257

[18] Debnath, Biplab K., Ujjwal K. Saha, and Niranjan Sahoo. "A comprehensive review on the application of emulsions as an alternative fuel for diesel engines." Renewable and Sustainable Energy Reviews 42 (2015): $196-211$. https://doi.org/10.1016/i.rser.2014.10.023

[19] Hasannuddin, A. K., J. Y. Wira, S. Sarah, WMN Wan Syaidatul Aqma, AR Abdul Hadi, N. Hirofumi, S. A. Aizam et al. "Performance, emissions and lubricant oil analysis of diesel engine running on emulsion fuel." Energy Conversion and Management 117 (2016): 548-557. https://doi.org/10.1016/i.enconman.2016.03.057

[20] Alahmer, Ali. "Influence of using emulsified diesel fuel on the performance and pollutants emitted from diesel engine." Energy Conversion and Management $73 \quad$ (2013): $361-369$. https://doi.org/10.1016/i.enconman.2013.05.012

[21] Ithnin, Ahmad Muhsin, Mohamad Azrin Ahmad, Muhammad Aiman Abu Bakar, Srithar Rajoo, and Wira Jazair Yahya. "Combustion performance and emission analysis of diesel engine fuelled with water-in-diesel emulsion fuel made from low-grade diesel fuel." Energy Conversion and Management 90 (2015): 375-382. https://doi.org/10.1016/j.enconman.2014.11.025 